\title{
Possible Therapeutic Effect of Stem Cell in Atherosclerosis in Albino Rats. A Histological and Immunohistochemical Study
}

\author{
Samraa H Abdel-Kawi ${ }^{1}$, Khalid S Hashem ${ }^{2}$ \\ ${ }^{1}$ Department of Histology, Faculty of Medicine, ${ }^{2}$ Department of Biochemistry, \\ Faculty of Veterinary, Beni-Suef University, Beni-suef, Egypt
}

Background: Atherosclerosis is the leading cause of death worldwide. there are no effective approaches to regressing atherosclerosis due to not fully understood mechanisms. Recently, stem cell-based therapies have held promises to various diseases, including vascular diseases.

Aim: The present study aimed at investigating the possible effect of cord blood mesenchymal stem cell (MSC) therapy on atherosclerosis.

Material and Methods: Eighty adult male albino rats were divided into control group (I), atherogenic group (II): subjected to high cholesterol fed diet $(200 \sim 300 \mathrm{mg} / \mathrm{kg}$ body weight) for 12 weeks and 1.8 million units of vitamin D / $\mathrm{kg}$ of diet for 6 weeks. Stem cell therapy group (III): injected with stem cells in the tail vein following confirmation of atherosclerosis. Histological, Immunohistochemical and morphometric studies were performed were conducted. Results: Atherogenic group (II) showed increased aortic thickness, intimal proliferation, smooth muscle proliferation and migration. Increased area $\%$ of collagen fibers, iNOS and vimentin immunoreactions were recorded and proved morphometrically. All findings regressed on stem cell therapy.

Conclusion: A definite therapeutic effect of mesenchymal stem cells was found on atherosclerosis.

Keywords: Mesenchymal stem cells, Atherosclerosis, Cord blood, eNOS, iNOS

\section{Introduction}

Atherosclerosis and its consequences remain a major global challenge. Coronary artery or cerebrovascular disease represents the leading cause of mortality worldwide (1). Apart from its lethal consequences such as myocardial infarction or stroke, atherosclerosis underlies the cause of

Accepted for publication May 19, 2015, Published online November 30, 2015 Correspondence to Samraa H Abdel-Kawi

Department of Histology, Faculty of Medicinel, Beni-Suef University, Mohammed Hassan street, Faculty of Medicine, Beni-suef 62511, Egypt

Tel: +201001916480, Fax: +20822321352

E-mail: samraahussein@yahoo.com

(a) This is an open-access article distributed under the terms of the Creative Commons Attribution Non-Commercial License (http://creativecommons.org/ licenses/by-nc/4.0/), which permits unrestricted non-commercial use, distribution, and reproduction in any medium, provided the original work is properly cited. huge burden of morbidity, associated with heart failure due to ischemic heart disease or neurological impairment due to stroke.

Over the past decades, therapeutic options to treat atherosclerosis or at least prevent its consequences have been significantly improved including new pharmacological treatments such as novel inhibitors of platelet aggregation (2) but also interventional techniques such as percutaneous coronary interventions (3). However, there is still an enormous unmet need. Thus novel treatment options are desperately needed in order to reduce morbidity and mortality due to atherosclerosis.

The traditional environmental risk factors for atherosclerosis are lifestyle choices, including intake of cholesterol-rich foods, low exercise level, and smoking. Low physical activity in combination with an unhealthy diet will elevate plasma levels of LDL (the bad cholesterol), lead to increased lipid accumulation both in the artery 
wall and in fat deposits, and increase the incidence of obesity and the risk of developing type 2 diabetes. Hypercholesterolemia is a major risk factor for the development and progression of atherosclerosis and related cardiovascular diseases (4).

Atherosclerosis, a chronic progressive inflammatory disease of the arterial wall, has traditionally been considered an "inside-out" response in which injury to intimal endothelial cells initiates the adhesion/invasion of inflammatory cells in the subendothelial space. Subsequently atherosclerotic plaques grow by the accumulation of inflammatory cells and lipid substances and the proliferation of vascular smooth muscle cells $(5,6)$. Clinical evidence indicates that instability rather than plaque size affects the prognosis of cardiovascular diseases $(7,8)$.

Stem cells are a population of undifferentiated cells which characterized by the ability to extensively proliferate (self-renewal), usually arise from a single cell (clonal), and differentiate into different types of cells and tissues (potent). It can make exact copies of itself indefinitely and can differentiate and produce specialized cells for the various tissues of the body. There are two types of stem cells: adult and embryonic. There are several sources of stem cells with varying potencies. Pluripotent cells are embryonic stem cells derived from the inner cell mass of the embryo that can differentiate into tissue from all 3 germ layers (endoderm, mesoderm and ectoderm). Multipotent stem cells may differentiate into tissue derived from a single germ layer such as mesenchymal stem cells which form adipose tissue, bone and cartilage. Tissue-resident stem cells are oligopotent since they can form terminally differentiated cells of a specific tissue. Stem cells can be used in cellular therapy to replace damaged cells or to regenerate organs (9).

There are four adult stem cells from common sources including, adipose tissue-mesenchymal stem cells (AT-MSC), bone marrow mesenchymal stem cells (BM-MSCs), nasal septum derived multipotent progenitors (NSP) and umbilical cord blood stem cells (USSCs) (10).

The use of stem cells in medicine is considered a promising untraditional field as many scientists and researchers anticipate that adult and embryonic stem cells will soon be able to treat cancer, Type 1 diabetes mellitus, Parkinson's disease, Brain damage, Spinal-cord injury, Heart damage, Hematopoiesis (blood-cell formation), Baldness, Missing teeth, Deafness, Blindness and vision impairment, Amyotrophic lateral sclerosis, Graft vs. host disease and Crohn's disease, Neural and behavioral birth defects, Diabetes, Transplantation, Orthopaedics, Wound healing, Infertility Huntington's disease, Celiac disease, cardiac failure, mus- cle damage and neurological disorders, and many others (11).

This study was conducted to monitor the effect of stem cells in vascular repair and reduction of atherosclerosis which brings worldwide benefits.

\section{Materials and Methods}

\section{Induction of atherosclerosis}

By giving a high cholesterol diet and high doses of vitamin D as follow; Rats will be given high cholesterol fed diet (200 300 mg/kg body weight) for 12 weeks and 1.8 million units/kg of vitamin D for 6 weeks (12).

\section{Animals}

Eighty male albino rats of 3 to 4 weeks-old, weighing $180 \pm 10 \mathrm{gm}$ housed at optimum conditions (temperature $\left[21 \pm 2^{\circ} \mathrm{C}\right]$, with a 12-h light/dark cycle), fed standard chow adlibitum with free access to water at all times for 1 week to acclimate the animals. The animals were treated according to animal rights committee. The animals then divided into 3 experimental groups $(n=20)$ :

Control group (I): where rats will be kept at optimum normal conditions.

Atherogenic group (II): where rats will be given High cholesterol fed diet (200 300 mg/kg body weight) for 12 weeks and 1.8 million units $/ \mathrm{kg}$ of vitamin $\mathrm{D}$ for 6 weeks (12).

Stem cells treated group (III): where rats will be given High cholesterol fed diet (200 300 mg/ $\mathrm{kg}$ body weight) for 12 weeks and 1.8 million units $/ \mathrm{kg}$ of vitamin $\mathrm{D}$ for 6 weeks. Following confirmation of atherosclerosis, the animals were injected each with $3 \times 10^{6}$ of cultured and labeled mesenchymal stem cells (MSCs) suspended in 0.5 $\mathrm{ml}$ phosphate buffer saline (PBS) on two successive days in the tail vein (13-15).

\section{Cord blood collection}

UCB was collected from warm blood full-term born rats immediately after birth. After clamping and disinfecting of the umbilical cord with $70 \%$ alcohol, the umbilical vein was punctured immediately after birth and UCB was drained by gravity into standard blood donor bag and subsequently stored at $4^{\circ} \mathrm{C}$. Samples were processed only if (i) at least $150 \mathrm{~mL}$ UCB was collected, (ii) storage time was less than 15 hours, and (iii) no signs of coagulation or hemolysis were present. Once the umbilical cord was ruptured, a clamp was placed on each end of the amniotic part, after which the umbilical cord was rinsed with tap water and iodine soap to remove the gross contamination and disinfected with $70 \%$ alcohol. Subsequently, a 
5-cm-long piece was obtained from the middle of the disinfected umbilical cord with a sterile scalpel blade and stored in phosphate-buffered saline containing $50 \mu \mathrm{g} / \mathrm{mL}$ gentamycin at $4^{\circ} \mathrm{C}(16)$.

\section{Isolation and culturing of mesenchymal stem cells (MSCs)}

Mononuclear cell fraction (MNCF) was isolated by loading $30 \mathrm{ml}$ of whole blood onto $10 \mathrm{ml}$ of Ficoll density media (Healthcare Bio-Sciences) in $50 \mathrm{ml}$ polypropylene tubes, centrifuge for 30 minutes at room temperature. The interphase collected after aspirating and discarding the supernatant, then was washed with $20 \mathrm{ml}$ PBS and centrifuged at room temperature. The supernatant was aspirated and cells were washed with PBS again. Cells were resuspended in the isolation media and transferred to culture dishes. Incubation was at $38.5^{\circ} \mathrm{C}$ in humidified atmosphere containing $5 \% \mathrm{CO}_{2}$. The isolation media was low glucose Dulbecco's modified Eagles medium (DMEM) (Cambrex Bio Science) supplemented with low dexamethazone $\left(10^{-7} \mathrm{M}\right)$ (Sigma-Aldrich), penicillin $(100 \mathrm{IU} / \mathrm{ml})$, streptomycin $(0.1 \mathrm{mg} / \mathrm{ml})$ (Invitrogen) and ultraglutamine (2 mM) (Cambrex Bio Science) (16).

MSCs in culture were characterized by their adhesiveness and fusiform shape. MSCs cells were harvested during the $4^{\text {th }}$ passage and were labeled with PKH26 red fluorochrome. Labeled cells retain both biological and proliferating activity. Labeled cells that have been washed can be visualized in culture up to 100 days after staining (for non-dividing cells). The dye itself is stable and will divide equally when the cells divide (17).

\section{Histological study}

Aortas were quickly excised after dissection of animals. The samples were preserved in $10 \%$ formol saline for 24 hours. Paraffin blocks were prepared and 5 um thick sections were subjected to hematoxylin and eosin (18) and Masson's trichrome (19).

\section{Immunohistochemichemical study}

Sections of aorta were deparaffinised and treated with PBS for $30 \mathrm{~min}$ at room temperature. The slides were incubated for $30 \mathrm{~min}$ with primary anti-eNOS (1:50 rabbit polyclonal, RR-1711-R7, Neomarkers; Lab Vision, Fermont, CA, USA), anti-INOS (mouse momoclonal antibody (BD transduction Lab, USA) and vimentin (1:500 dilution; BioGenex) antibodies. After three washes with PBS, the sections were incubated with biotinylated secondary antibody, and incubated with peroxidase substrate. Antibody labeled specimens were rinsed with distilled water for 5 min and dehydrated. Positive cytoplasmic immune re- action appeared as brown dots against blue background of Mayer's hematoxylin stain $(20,21)$.

\section{Statistical analysis}

Quantitative data were summarized as means and standard deviations as compared using one-way analysis-of-variance (ANOVA). p-values 0.05 were considered statistically significant. Calculations were made on SPSS software (22).

\section{Results}

\section{Hematoxylin and eosin (H\&E) stained sections}

Section of aorta of control rats (group I) demonstrated that its wall is formed of three layers tunica intima, tunica media and tunica adventitia (Fig. 1A). Closer observation revealed the tunica intima exhibiting simple squamous endothelium with underlying lamina propria. tunica media formed of concentrically-arranged smooth muscle (Fig. 1B) and tunica adventitia exhibiting vasa vasorum (Fig. 1A).

In atherogenic rats (group II), sections of Aorta showed thickening of tuinca intima with fat deposition (Fig. 1C, D). Tunica media demonstrated foam cells (Fig. 1C, D) and smooth muscle proliferation with migration of smooth muscle fibers into intima (Fig. 1E, F). Thickness of the whole wall was significantly increased compared to control group (Table 1) (Fig. 1E, F). Some fields showed thinning of adventitia (Fig. 1G) and inflammatory cells (Fig. 1C).

In stem cell therapy group (group III), no intimal thickening, tunica media appears normal except some foam cells and congested vasa vasorum within tunica adventitia (Fig. 1H). Thickness of the whole wall was significantly decreased compared to atherogenic group (Table 1).

\section{Masson's trichrome stained sections}

Minimal collagen fibers were found in sections of aorta of control rats (group I) (Fig. 2A). While in atherogenic rats (group II), extensive collagen fibers demonstrated (Fig. 2B) which were significantly increased compared to control group (Table 1). In stem cell therapy group (group III), minimal collagen fibers were seen in detected and significantly decreased compared to atherogenic group (Table 1) (Fig. 2C).

\section{Vimentin immunostained sections}

There is a significant increase in vimentin immunoreactivity in atherogenic group (group II), compared with normal control group (group I) while stem cell therapy group (group III) showed a siginificant decrease in vimentin immunoreactivity compared to atherogenic group 

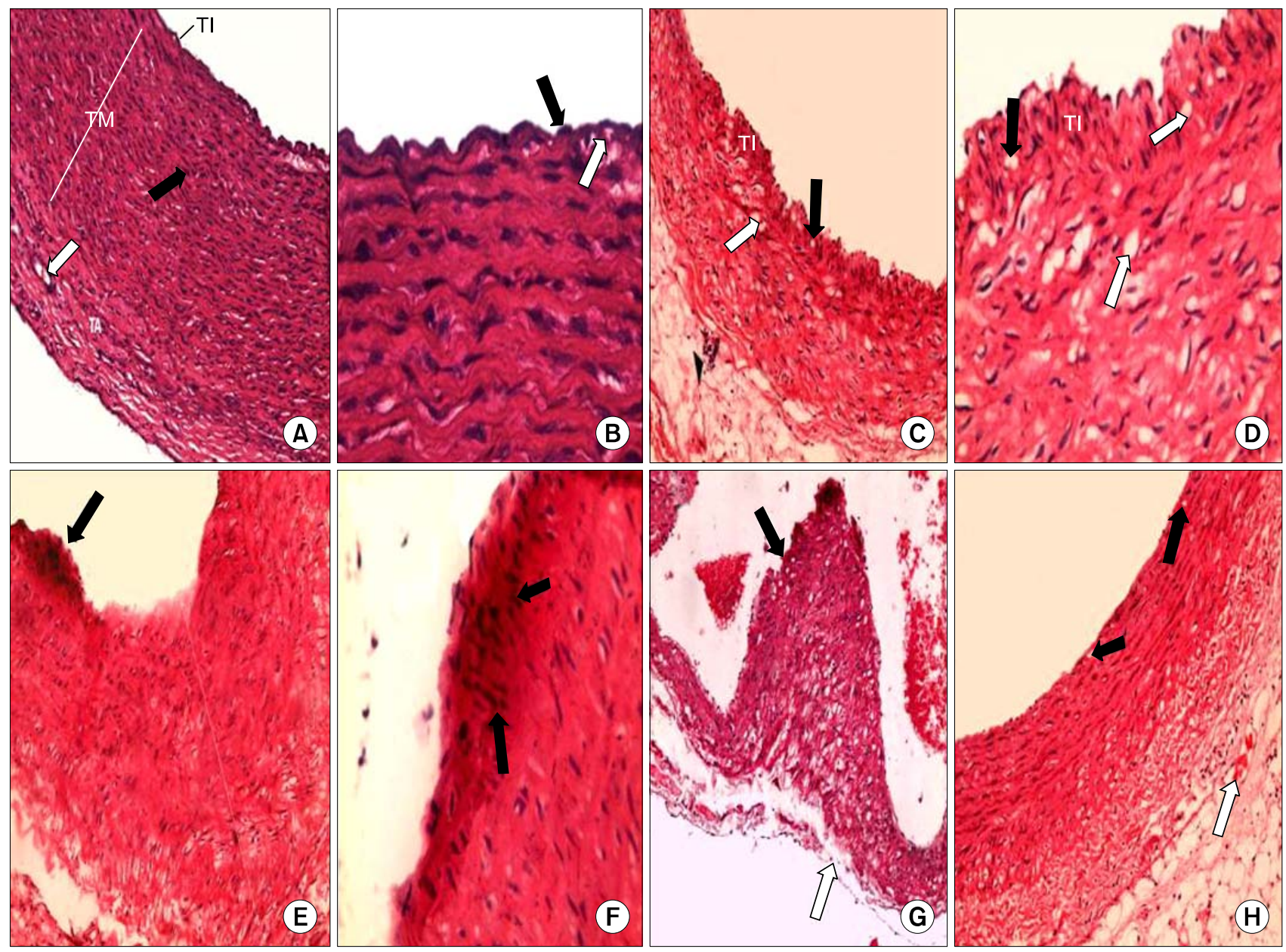

Fig. 1. (A) Three layers forming wall of aorta: tunica intima (TI), tunica media (TM) formed of concentrically-arranged smooth muscle (black arrow) and tunica adventitia (TA) exhibiting vasa vasorum (white arrow) (group I, H\&E, $\times 200$ ). (B) Tunica intima exhibiting simple squamous endothelium (black arrow) with underlying lamina propria (white arrow) (group I, H\&E, $\times 400$ ). (C) Thickening of tunica intima (TI) with fat deposition (black arrow) and appearance of foam cells (white arrow). Tunica adventitia shows inflammatory reaction (arrow heads) (group II, H\&E, $\times 200$ ). (D) Thickening of tunica intima (TI) with fat deposition (black arrow) and appearance of foam cells (white arrow) (group II, H\&E, $\times 400$ ). (E) Increased thickness of the whole wall of aorta (double headed arrow) with protrusion of intima into lumen (black arrow) (group II, H\&E, $\times 200$ ). (F) Smooth muscle proliferation and migration into intima (black arrow) (group II, H\&E, $\times 400$ ). (G) Thickened wall of aorta with protrusion into lumen (black arrow) and thinning of adventitia (white arrow) (group II, H\&E, $\times 200$ ). (H) normal aorta except tunica media show some foam cells (black arrow) and congested vasa vasorum within tunica adventitia (white arrow) (group III, $\mathrm{H} \& \mathrm{E}, \times 200)$.

Table 1. Aortic wall thickness and area $\%$ of collagen fibers distribution eNOS, iNOS and vimentin immune-reaction of of Aorta in all groups

\begin{tabular}{lccc}
\hline & Group I (Control) & Group II (atherogenic) & Group III (stem cell) \\
\hline Aortic wall thickness & $80.79 \pm 1.38$ & $124.70 \pm 8.40^{\mathrm{a}}$ & $83.25 \pm 1.66^{\mathrm{b}}$ \\
Area \% of collagen fibers & $8.79 \pm 0.873$ & $13.06 \pm 1.934^{\mathrm{a}}$ & $8.13 \pm 0.743^{\mathrm{b}}$ \\
Area \% of vimentin immune-reaction & $1.08 \pm 0.43$ & $5.16 \pm 0.73^{\mathrm{a}}$ & $1.09 \pm 1.01^{\mathrm{b}}$ \\
Area \% of eNOS immune-reaction & $2.56 \pm 0.538$ & $1.61 \pm 0.66^{\mathrm{a}}$ & $1.64 \pm 1.01^{\mathrm{b}}$ \\
Area \% of iNOS immune-reaction & $0.76 \pm 0.07$ & $3.01 \pm 0.14^{\mathrm{a}}$ & $1.08 \pm 0.19^{\mathrm{b}}$ \\
\hline
\end{tabular}

asignificant compared to control group, ${ }^{b}$ significant compared to atherogenic group $p<0.05$. 

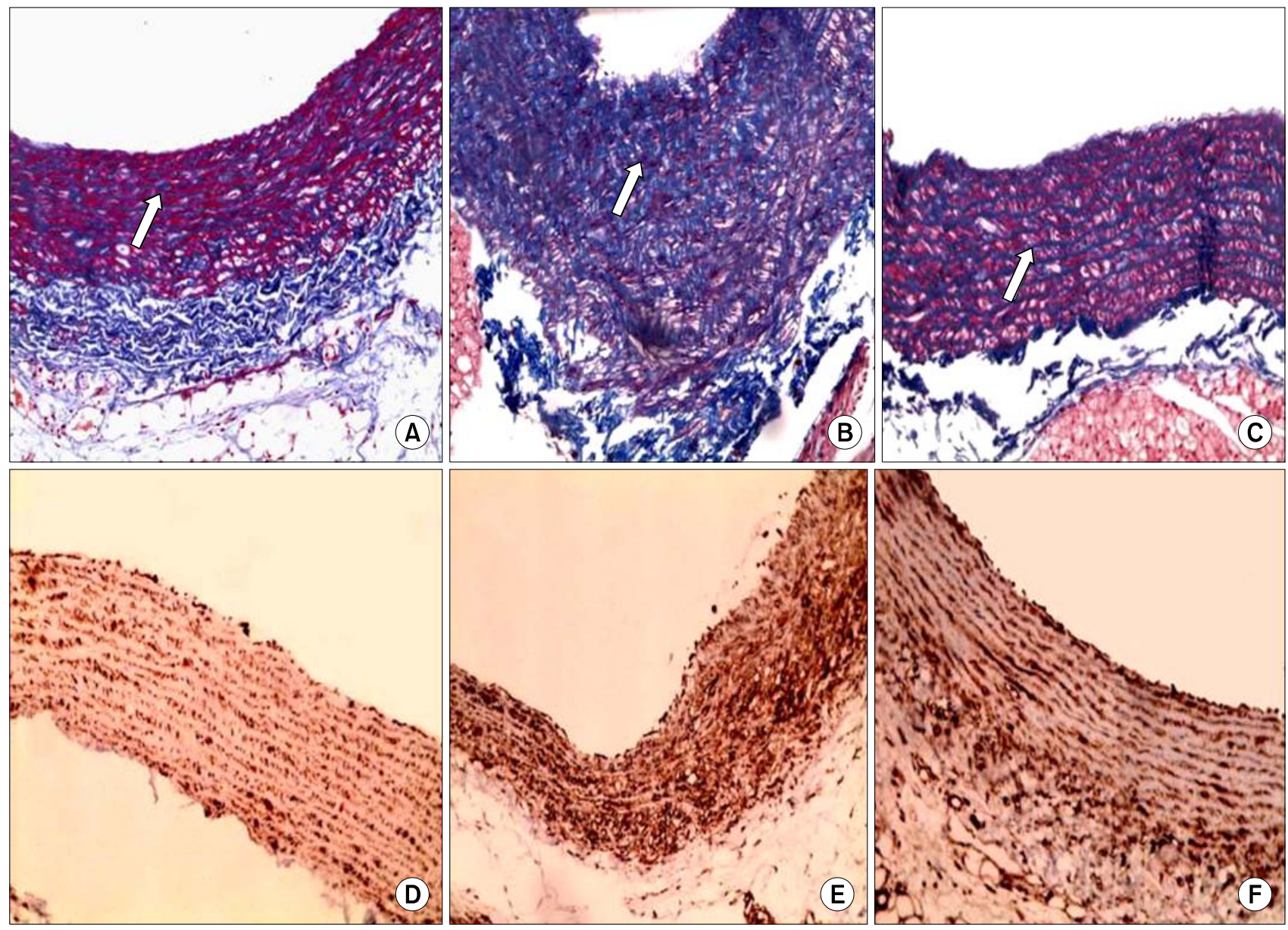

Fig. 2. (A) Minimal collagen fibers (arrows) (group I). (B) Extensive collagen fibers (arrows) (group II). (C) Minimal collagen fibers (arrows) (group II) (Masson' trichrome, $\times 200$ ). (D) Minimal vimentin immunoreactivity (group i). (E) Increased vimentin immunoreactivity (group II). (F) Minimal vimentin immunoreactivity (group III) (immunostaining for vimentin $\times 200$ ).

(Table 1) (Fig. 2D F).

\section{eNOS immunostained sections}

There is a significant decrease in eNOS immunoreactivity in atherogenic group (group II), compared with normal control group (group I) while stem cell therapy group (group III) showed a significant increase in eNOS immunoreactivity compared to atherogenic group (Table 1) (Fig. 3A C).

\section{iNOS immunostained sections}

There is a significant increase in iNOS immunoreactivity in atherogenic group (group II), compared with normal control group (group I) while stem cell therapy group (group III) showed a significant decrease in iNOS immunoreactivity comperd to atherogenic group (Table 1) (Fig. 3D F).

\section{Homing of transplanted MSCs}

Positive PKH 26 immunofluorescent stem cells were detected within aortic sections from stem cell therapy group (group III) (Fig. 4) indicating homing of stem cells in the injured aortic tissues.

\section{Morphometric results}

The mean thickness of the wall of aorta was significantly increased in atherogenic group compared to control and stem cell therapy groups. Similar significance was recorded as regards the mean area $\%$ of collagen fibers, vimentin and iNOS immunoreactivity. While there was a significant decrease in eNOS immunoreactivity increased in atherogenic group (group II) compared to control and stem cell therapy groups (Table 1). 

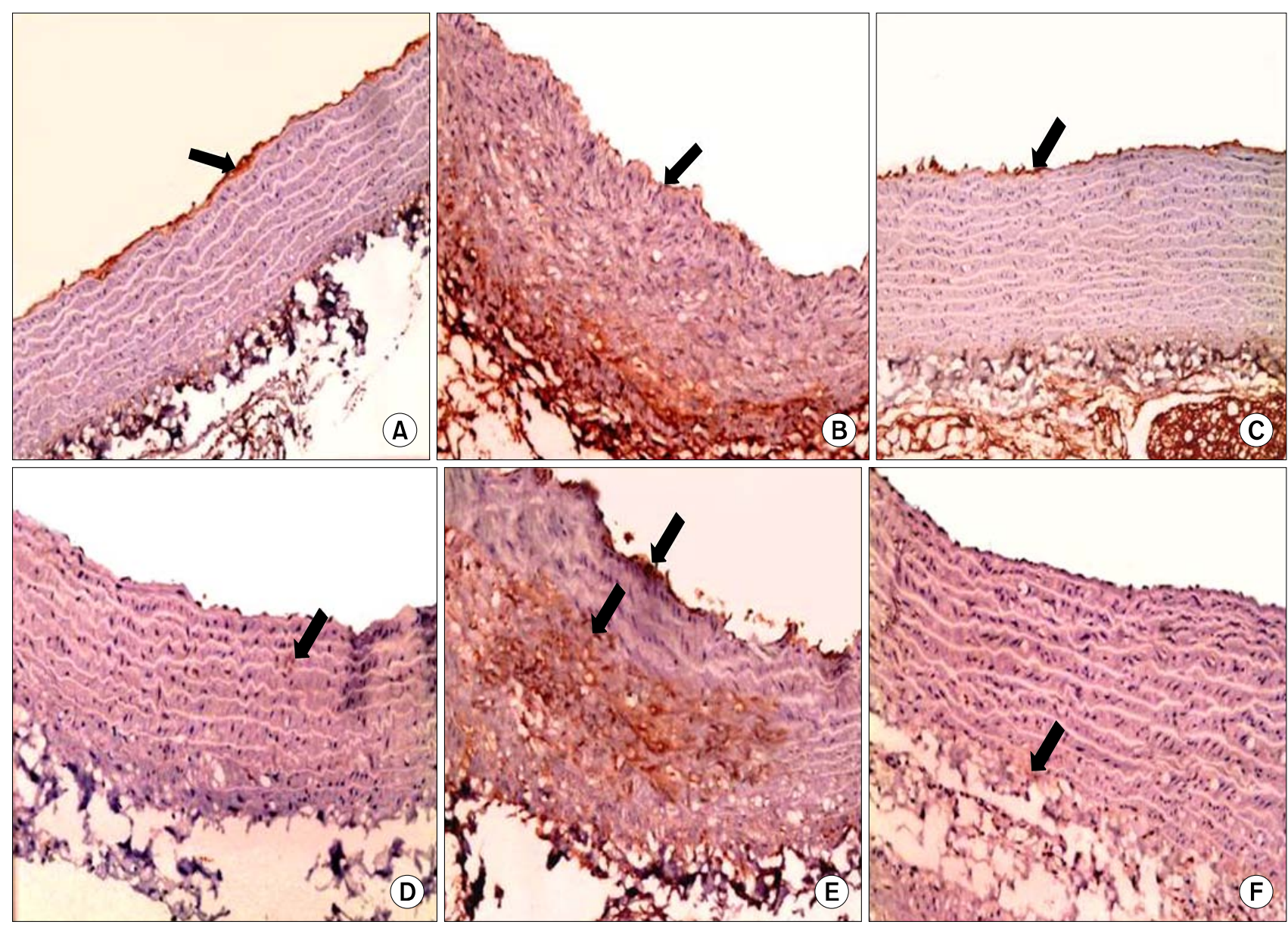

Fig. 3. (A) eNOS immunoreactivity in tunica intima (arrows) (group I). (B) Weak eNOS immunoreactivity in tunica intima (arrows) (group II). (C) eNOS immunoreactivity in tunica intima (group III) (immunostainig for eNOS, $\times 200$ ). (D) Weak iNOS immunoreactivity (arrows) (group I). (E) increased iNOS immunoreactivity (arrows) (group II). (F) Weak iNOS immunoreactivity (arrows) (group III) (immunostainig for iNOS, $\times 200)$.

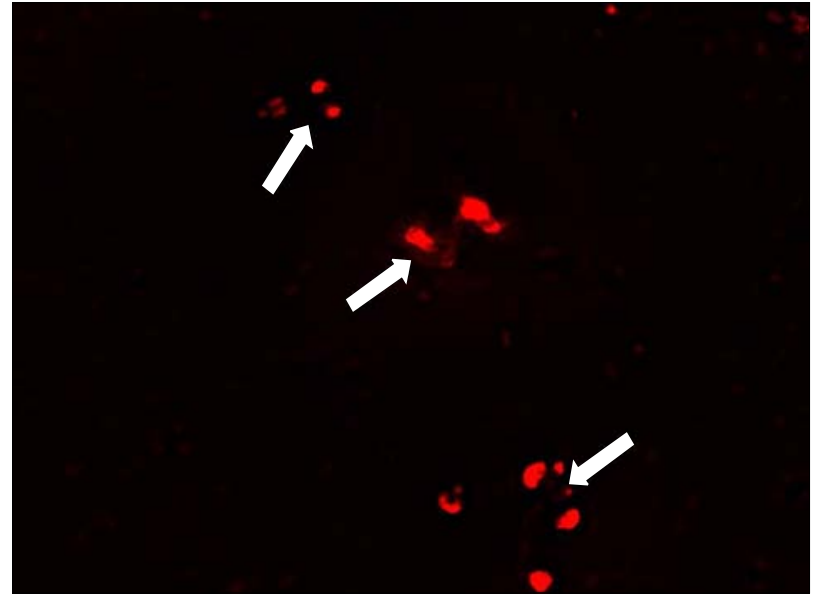

Fig. 4. A photomicrograph of section of aorta from group III showing positive immunofluorescent stem cells (arrows) within aorta.

\section{Discussion}

The current study demonstrated modulating effect of cord blood stem cell therapy on atherosclerosis in albino rat. This was evidenced by histological, Immunohistochemical and morphometric studies.

By examination, high cholesterol diet and high doses of vitamin $\mathrm{D}$ resulted in significant increase in wall thickness, thickening of tunica intima with fat deposition and appearance of foam cells which is in accordance with the work of other investigators (23-25). Tang et al. (26) demonstrated that hypercholesterolemia is accompanied by lipid deposition in the vessel resulting in foam cell and plaque formation.

The lesions of atherosclerosis represent a series of highly specific cellular and molecular responses. The earliest changes that precede the formation of lesions of athero- 
sclerosis take place in the endothelium, with resultant endothelial dysfunction. Endothelium dysfunction can result in increased lipid permeability, macrophage recruitment, formation of foam cells, and recruitment of T-lymphocytes and platelet (27).

Tietge (28) declared that lipid deposition and accumulation within vascular wall is the initial stage of atherogenesis. Thereafter inflammatory cells such as monocytes and neutrophils infiltrate and engulf these lipid molecules, and then subsequently turn into foam cells and simultaneously produce a substantial of inflammatory cytokines such as interleukins and CRP. Oxidation of low density lipoprotein (LDL) is believed to play a role in the initiation of atherosclerosis, leading to LDL uptake by macrophages and foam-cell formation, but becoming less important in the later stages of the condition (29).

Our results demonstrated smooth muscle proliferation with migration of smooth muscle fibers into intima. The results were confirmed by Rudijanto (27), who declared that after intimal injury, different cell types, including endothelial cells, platelets, and inflammatory cells release mediators, such as growth factors and cytokines that induce phenotype change of vascular smooth muscle cells from the quiescent "contractile" phenotype state to the active "synthetic" state, that can migrate and proliferate from media to the intima.

The present study reported an increase in collagen fibers of the atherogenic group as evidenced by Masson's trichrome and vimentin immunostaining. Collagen is believed to be produced by smooth muscle cells (30) forming unusual and distinctive type of fibrous tissue.

Diet-induced hypercholesterolemia in rats resulted in a significant decrease in aortic eNOS activity coupled with increased aortic iNOS activity which is consistent with the studies of Verbeuren et al. (31) and Li et al. (32). Current findings could be attributed to hypercholesterolemia-induced oxidative stress leading eventually to endothelial dysfunction (33).

In stem cell therapy group, all morphological changes have been disappeared except for some foam cells and slight congestion of vasa vasorum. This was proved morpmometrically. Niyaz et al. (34) reported that mesenchymal stem cells can participate in the regeneration and repair of diseased adult organs including the blood vessels.

It was reported that MSCs express intermediate to low levels of human leucocytic antigen (HLA) class I, low levels of HLA class II and low levels of co-stimulatory molecules allowing the MSCs to escape alloreactive recognition. These properties result in modulation of the immune response by MSCs and have been the basis for clinical trials of allogenic MSC administration to patients (35).

Ji et al. (36) added that one concern in the use of transplantation of non-hematopoietic stem cells from human umbilical cord blood (UCB-nHSCs) is the possibility of rejection by the host's immune system. They showed that both UCB-nHSCs and their progenies have no significant effects on proliferation of xenogenic $\mathrm{T}$ lymphocytes. UCB-nHSCs are shown to induce a lower level of CD4 and CD8 expression in the brain and in the peripheral blood indicating that both undifferentiated and differentiated UCB-nHSCs all have weak immunogenicity.

The mechanisms that regulate mobilization, migration, and differentiation of stem cells and their homing to sites of vascular injury are complex and involve several mediators and receptors, such as P-selectin glycoprotein ligand-1 (PSGL-1), $\alpha_{4}$ integrin, CXC chemokine receptor-2 and -4 , and $\beta_{1^{-}}$and $\beta_{2}$-integrins (17-20). Furthermore, it has been shown that the interaction of platelets with progenitor cells influences their chemotaxis, adhesion, activation, and differentiation into mature endothelial cells during vascular repair (37).

Platelets are involved in progenitor cells homing by releasing potent chemotactic factors such as the stromal-cell-derived factor-1 (SDF-1 $\alpha$ ). In an in vitro model it was shown that a significant interaction occurs between activated platelets and EPCs under both static and flow conditions, and this interaction is mediated by P-selectin-P-selectin glycoprotein ligand-1 (PSGL-1) binding and $\beta 1$ - and $\beta 2$ integrins (38).

In vivo experiments of carotid injury in mice have reported that platelets provide a critical signal for the early recruitment of bone marrow (BM) -derived progenitor cells, such as CD34+ cells, to the sites of vascular injury. Apart from EPC homing to sites of vascular injury, platelets support and promote the maturation and differentiation of EPCs to endothelial cells (ECs) (39).

eNOS, the predominant NOS isoform in the vasculature, is responsible for most of the $\mathrm{NO}$. produced in this tissue. Vascular NO dilates all types of blood vessels by stimulating soluble guanylyl cyclase and increasing cyclic guanosine monophosphate (cGMP) in smooth muscle cells. NO released toward the vascular lumen is a potent inhibitor of platelet aggregation and adhesion. NO- also can inhibit leukocyte adhesion to the vessel wall either by interfering with the ability of the leukocyte adhesion molecule CD11/CD18 to form an adhesive bond with the endothelial cell surface or by suppressing CD11/CD18 expression on leukocytes. White cell adherence is an early event in the development of atherosclerosis; therefore, NOmay protect against the onset of atherogenesis. Furthermore, 
NO has been shown to inhibit DNA synthesis, mitogenesis, and proliferation of vascular smooth muscle cells. The inhibition of platelet aggregation and adhesion protects smooth muscle from exposure to platelet-derived growth factor(s). Therefore, NO also prevents a later step in atherogenesis, fibrous plaque formation. Based on the combination of those effects, endothelial NO probably represents the most important antiatherogenic defense principle in the vasculature (40). In our study we showed that in stem cell therapy group, there was a significant increase in eNOS immunoreactivity. This may declare that stem cell can differentiate into endothelaial cells.

\section{Conclusion}

Thus, the present study demonstrates that cord blood mesenchymal stem cells could offer a a novel therapeutic opportunity against diet-induced atherosclerosis in rats. Our study opens the perspective to clinical studies.

\section{Acknowledgment}

This study was funded from Beni-Suef University, Unit of project financing.

\section{Potential conflict of interest}

The authors have no conflicting financial interest.

\section{References}

1. Go AS, Mozaffarian D, Roger VL, Benjamin EJ, Berry JD, Blaha MJ, Dai S, Ford ES, Fox CS, Franco S, Fullerton HJ, Gillespie C, Hailpern SM, Heit JA, Howard VJ, Huffman MD, Judd SE, Kissela BM, Kittner SJ, Lackland DT, Lichtman JH, Lisabeth LD, Mackey RH, Magid DJ, Marcus GM, Marelli A, Matchar DB, McGuire DK, Mohler ER 3rd, Moy CS, Mussolino ME, Neumar RW, Nichol G, Pandey DK, Paynter NP, Reeves MJ, Sorlie PD, Stein J, Towfighi A, Turan TN, Virani SS, Wong ND, Woo D, Turner MB; American Heart Association Statistics Committee and Stroke Statistics Subcommittee. Executive summary: heart disease and stroke statistics--2014 update: a report from the American Heart Association. Circulation 2014;129:399-410

2. Cannon CP, Harrington RA, James S, Ardissino D, Becker RC, Emanuelsson H, Husted S, Katus H, Keltai M, Khurmi NS, Kontny F, Lewis BS, Steg PG, Storey RF, Wojdyla D, Wallentin L; PLATelet inhibition and patient Outcomes Investigators. Comparison of ticagrelor with clopidogrel in patients with a planned invasive strategy for acute coronary syndromes (PLATO): a randomised double-blind study. Lancet 2010;375:283-293

3. Meier P, Timmis A. Almanac 2012: interventional cardiol- ogy: the national society journals present selected research that has driven recent advances in clinical cardiology. Heart 2012;98:1701-1709

4. Chin-Dusting JP, Shaw JA. Lipids and atherosclerosis: clinical management of hypercholesterolaemia. Expert Opin Pharmacother 2001;2:419-430

5. Ross R. Atherosclerosis--an inflammatory disease. N Engl J Med 1999;340:115-126

6. Libby P. Inflammation in atherosclerosis. Nature 2002; 420:868-874

7. Burke AP, Farb A, Malcom GT, Liang YH, Smialek J, Virmani R. Coronary risk factors and plaque morphology in men with coronary disease who died suddenly. N Engl J Med 1997;336:1276-1282

8. Redgrave JN, Lovett JK, Gallagher PJ, Rothwell PM. Histological assessment of 526 symptomatic carotid plaques in relation to the nature and timing of ischemic symptoms: the Oxford plaque study. Circulation 2006;113:2320-2328

9. Kolios G, Moodley Y. Introduction to stem cells and regenerative medicine. Respiration 2013;85:3-10

10. Adegani FJ, Langroudi L, Arefian E, Shafiee A, Dinarvand P, Soleimani M. A comparison of pluripotency and differentiation status of four mesenchymal adult stem cells. Mol Biol Rep 2013;40:3693-3703

11. Singec I, Jandial R, Crain A, Nikkhah G, Snyder EY. The leading edge of stem cell therapeutics. Annu Rev Med 2007;58:313-328

12. Kunitomo M, Kinoshita K, Bandô Y. Experimental atherosclerosis in rats fed a vitamin $\mathrm{D}$, cholesterol-rich diet. J Pharmacobiodyn 1981;4:718-723

13. Ma N, Stamm C, Kaminski A, Li W, Kleine HD, Müller-Hilke B, Zhang L, Ladilov Y, Egger D, Steinhoff G. Human cord blood cells induce angiogenesis following myocardial infarction in NOD/scid-mice. Cardiovasc Res 2005;66:45-54

14. Finney MR, Greco NJ, Haynesworth SE, Martin JM, Hedrick DP, Swan JZ, Winter DG, Kadereit S, Joseph ME, Fu P, Pompili VJ, Laughlin MJ. Direct comparison of umbilical cord blood versus bone marrow-derived endothelial precursor cells in mediating neovascularization in response to vascular ischemia. Biol Blood Marrow Transplant 2006;12:585-593

15. Seghatoleslam $M$, Jalali $M$, Nikravesh $M R$, Hosseini $M$, Hamidi Alamdari D, Fazel A. Therapeutic benefit of intravenous administration of human umbilical cord bloodmononuclear cells following intracerebral hemorrhage in rat. Iran J Basic Med Sci 2012;15:860-872

16. Koch TG, Heerkens T, Thomsen PD, Betts DH. Isolation of mesenchymal stem cells from equine umbilical cord blood. BMC Biotechnol 2007;7:26

17. Alhadlaq A, Mao JJ. Mesenchymal stem cells: isolation and therapeutics. Stem Cells Dev 2004;13:436-448

18. Kiernan JA. Histological and histochemical methods: theory and practice. 3rd ed. London, New York and New Delhi: Arnold publisher; 2001. 111-162

19. Bancroft JD, Gamble M. Theory and practice of histological 
techniques. 6th ed. London, UK: Churchil Livingstone; 2007

20. Martins AR, Zanella CA, Zucchi FC, Dombroski TC, Costa ET, Guethe LM, Oliveira AO, Donatti AL, Neder L, Chimelli L, De Nucci G, Lee-Ho P, Murad F. Immunolocalization of nitric oxide synthase isoforms in human archival and rat tissues, and cultured cells. J Neurosci Methods 2011;198:16-22

21. Schmid E, Osborn M, Rungger-Brändle E, Gabbiani G, Weber K, Franke WW. Distribution of vimentin and desmin filaments in smooth muscle tissue of mammalian and avian aorta. Exp Cell Res 1982;137:329-340

22. Emsley R, Dunn G, White IR. Mediation and moderation of treatment effects in randomised controlled trials of complex interventions. Stat Methods Med Res 2010;19:237-270

23. Wu Y, Li J, Wang J, Si Q, Zhang J, Jiang Y, Chu L. Anti-atherogenic effects of centipede acidic protein in rats fed an atherogenic diet. J Ethnopharmacol 2009;122:509-516

24. Attia HF, Soliman MM, Ismail TA. Protective effect of vitamin e and selenium on the liver, heart and aorta. J Vet Anat 2012;5:17-29

25. Gocmen AY, Ocak GA, Ozbilim G, Delibas N, Gumuslu S. Effect of atorvastatin on atherosclerotic plaque formation and platelet activation in hypercholesterolemic rats. Can J Physiol Pharmacol 2013;91:680-685

26. Tang FT, Chen SR, Wu XQ, Wang TQ, Chen JW, Li J, Bao LP, Huang HQ, Liu PQ. Hypercholesterolemia accelerates vascular calcification induced by excessive vitamin D via oxidative stress. Calcif Tissue Int 2006;79:326-339

27. Rudijanto A. The role of vascular smooth muscle cells on the pathogenesis of atherosclerosis. Acta Med Indones 2007;39:86-93

28. Tietge UJ. Hyperlipidemia and cardiovascular disease: inflammation, dyslipidemia, and atherosclerosis. Curr Opin Lipidol 2014;25:94-95

29. Yoshida H. Front line of oxidized lipoproteins: role of oxidized lipoproteins in atherogenesis and cardiovascular disease risk. Rinsho Byori 2010;58:622-630

30. Ross R. Rous-Whipple Award Lecture. Atherosclerosis: a defense mechanism gone awry. Am J Pathol 1993;143: 987-1002

31. Verbeuren TJ, Bonhomme E, Laubie M, Simonet S. Evidence for induction of nonendothelial NO synthase in aortas of cholesterol-fed rabbits. J Cardiovasc Pharmacol $1993 ; 21: 841-845$
32. Li R, Wang WQ, Zhang H, Yang X, Fan Q, Christopher TA, Lopez BL, Tao L, Goldstein BJ, Gao F, Ma XL. Adiponectin improves endothelial function in hyperlipidemic rats by reducing oxidative/nitrative stress and differential regulation of eNOS/iNOS activity. Am J Physiol Endocrinol Metab 2007;293:E1703-E1708

33. Anderson TJ. Oxidative stress, endothelial function and coronary atherosclerosis. Cardiologia 1997;42:701-714

34. Niyaz M, Gürpınar ÖA, Oktar GL, Günaydın S, Onur MA, Özsin KK, Yener A. Effects of VEGF and MSCs on vascular regeneration in a trauma model in rats. Wound Repair Regen 2015 Mar 7. doi: 10.1111/wrr.12278. [Epub ahead of print]

35. Lanzoni G, Roda G, Belluzzi A, Roda E, Bagnara GP. Inflammatory bowel disease: Moving toward a stem cellbased therapy. World J Gastroenterol 2008;14:4616-4626

36. Ji F, Wang Y, Sun H, Du J, Zhao H, Wang D, Xu Q, Duan D, Yang H. Human umbilical cord blood-derived non-hematopoietic stem cells suppress lymphocyte proliferation and CD4, CD8 expression. J Neuroimmunol 2008;197:99-109

37. de Boer HC, Verseyden C, Ulfman LH, Zwaginga JJ, Bot I, Biessen EA, Rabelink TJ, van Zonneveld AJ. Fibrin and activated platelets cooperatively guide stem cells to a vascular injury and promote differentiation towards an endothelial cell phenotype. Arterioscler Thromb Vasc Biol 2006;26:1653-1659

38. Langer H, May AE, Daub K, Heinzmann U, Lang P, Schumm M, Vestweber D, Massberg S, Schönberger T, Pfisterer I, Hatzopoulos AK, Gawaz M. Adherent platelets recruit and induce differentiation of murine embryonic endothelial progenitor cells to mature endothelial cells in vitro. Circ Res 2006;98:e2-e10

39. Massberg S, Konrad I, Schürzinger K, Lorenz M, Schneider S, Zohlnhoefer D, Hoppe K, Schiemann M, Kennerknecht E, Sauer S, Schulz C, Kerstan S, Rudelius M, Seidl S, Sorge F, Langer H, Peluso M, Goyal P, Vestweber D, Emambokus NR, Busch DH, Frampton J, Gawaz M. Platelets secrete stromal cell-derived factor lalpha and recruit bone marrow-derived progenitor cells to arterial thrombi in vivo. J Exp Med 2006;203:1221-1233

40. Förstermann U, Münzel T. Endothelial nitric oxide synthase in vascular disease: from marvel to menace. Circulation 2006;113:1708-1714 